\title{
DIAMOND PROSPECTIVITY OF THE ALTJAWARRA CRATON, AUSTRALIA
}

\author{
Linda A Tompkins ${ }^{1}$, Wayne Taylor ${ }^{1}$ and Duncan Cowan ${ }^{2}$ \\ ${ }^{1}$ Elkedra Diamonds NL, Australia; ${ }^{2}$ Cowan Geodata Services, Australia
}

\section{INTRODUCTION}

The selection of prospective areas for diamond exploration in Australia has recently been supported by the availability of government-sponsored regional datasets that now cover most of the continent. Based on a study of crustal elements in Precambrian northern Australia the buried Altjawarra Craton in the Northern Territory, Australia is highlighted as an area favourable for the emplacement of economic diamond pipes younger than about $500 \mathrm{Ma}$. Compilations utilized in the study include: seismic tomography (Australian SKIPPY project; Kennett, 1997; Van der Hilst et al., 1998; Debayle and Kennett, 2000); regional aeromagnetic data (Milligan and Tarlowski, 1999), crustal temperature and thickness data (Sommerville et al., 1994; Clitheroe et al., 1998), as well as new interpretations of the structure and tectonic history of the Precambrian crustal elements that make up the North Australian Craton (Shaw et al., 1996; Myers et al., 1996; Scott et al., 2000).

\section{REGIONAL SETTING}

Geographically, the Altjawarra Craton is located in central Australia about half way between the towns of Alice Springs in the Northern Territory and Mt Isa Queensland (Figure 1).

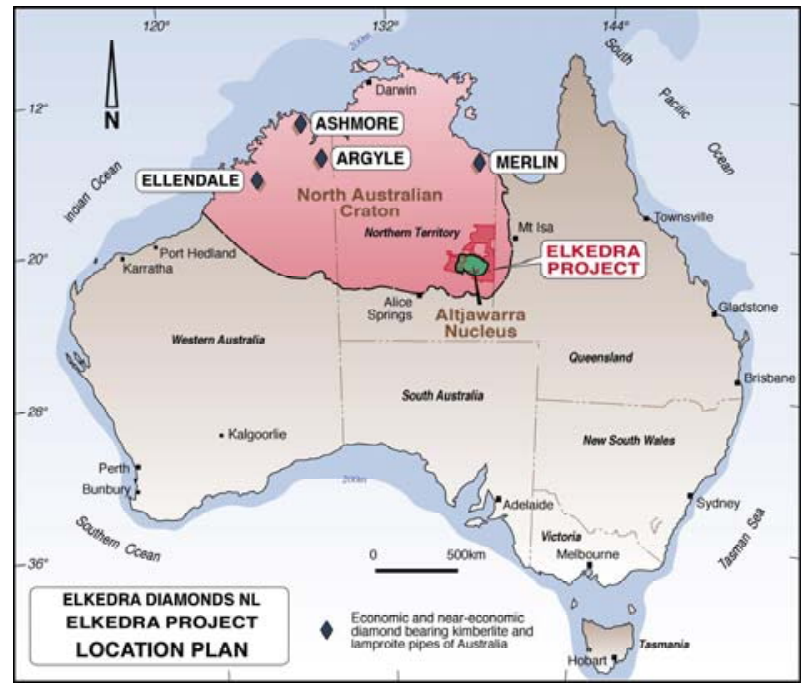

Figure 1: Location of the Altjawarra Craton.
The physiography is variable ranging from elevated dissected plateaus to broad alluvial to sandy flats, giving way to remote expansive sand plains with stabilized longitudinal dunes. Exploration ground access to much of the area is by helicopter assisted programs.

\section{North Australian Craton}

The little-known, wholly platform-sediment-covered Altjawarra block of Myers et al. (1996) lies within the south-east region of the large North Australian Craton (Figure 1). The North Australian Craton is a composite terrane made up of numerous continental blocks amalgamated in the Early Proterozoic era, approximately 1,800 million years ago. The importance of the North Australian Craton from a diamond prospectivity viewpoint is that it hosts all of Australia's primary diamond producing deposits. Specifically, the Merlin kimberlite province in the north eastern region of the North Australian Craton and the Argyle and Ellendale provinces which are characterized by diamondiferous lamproites.

\section{SOUTH GEORGINA BASIN}

The Altjawarra Craton is completely buried beneath thick Cambro-Ordovician sediments of the southern Georgina Basin. The sedimentary package is composed of calcareous siltstone and sandstone, limestone, dolostone and black shale.

\section{THE ALTJAWARRA CRATON}

The Altjawarra Craton is comprised of a central, geophysically-distinct zone referred to as the Altjawarra Cratonic Nucleus, and adjacent, related crustal elements. While the Altjawarra Craton is veneered by Georgina Basin sediments, recent GPS-located aeromagnetic data flown by the Northern Territory government, coupled with isolated petroleum and stratigraphic drillholes intersecting the basement, enable a regional geological model of the craton to be inferred.

\section{GEOPHYSICAL FEATURES}

The crystalline basement of the Altjawarra Craton has varied magnetic relief and texture with large areas of 
low amplitude and rugose texture, typical of granitoid granite gneiss terranes (Figure 2). These areas are separated by narrow, high amplitude $(\sim 1000 \mathrm{nT})$ linear and curvilinear anomalies, interpreted as complexly folded and faulted mafic and ultramafic units. There are a large number of plug-like magnetic anomalies varying in size from a few hundred metres to several kilometres.
Argadargarda Rift and is situated closer to the centre of the Georgina Basin.

Two large, circular magnetic features, possibly representing younger Mesoproterozoic gneiss and granitoids, lie to the west of the central Altjawarra Cratonic Nucleus. The northern (Ooratippra) magnetic anomaly represents a composite feature, with a pronounced east-west striking, high-amplitude

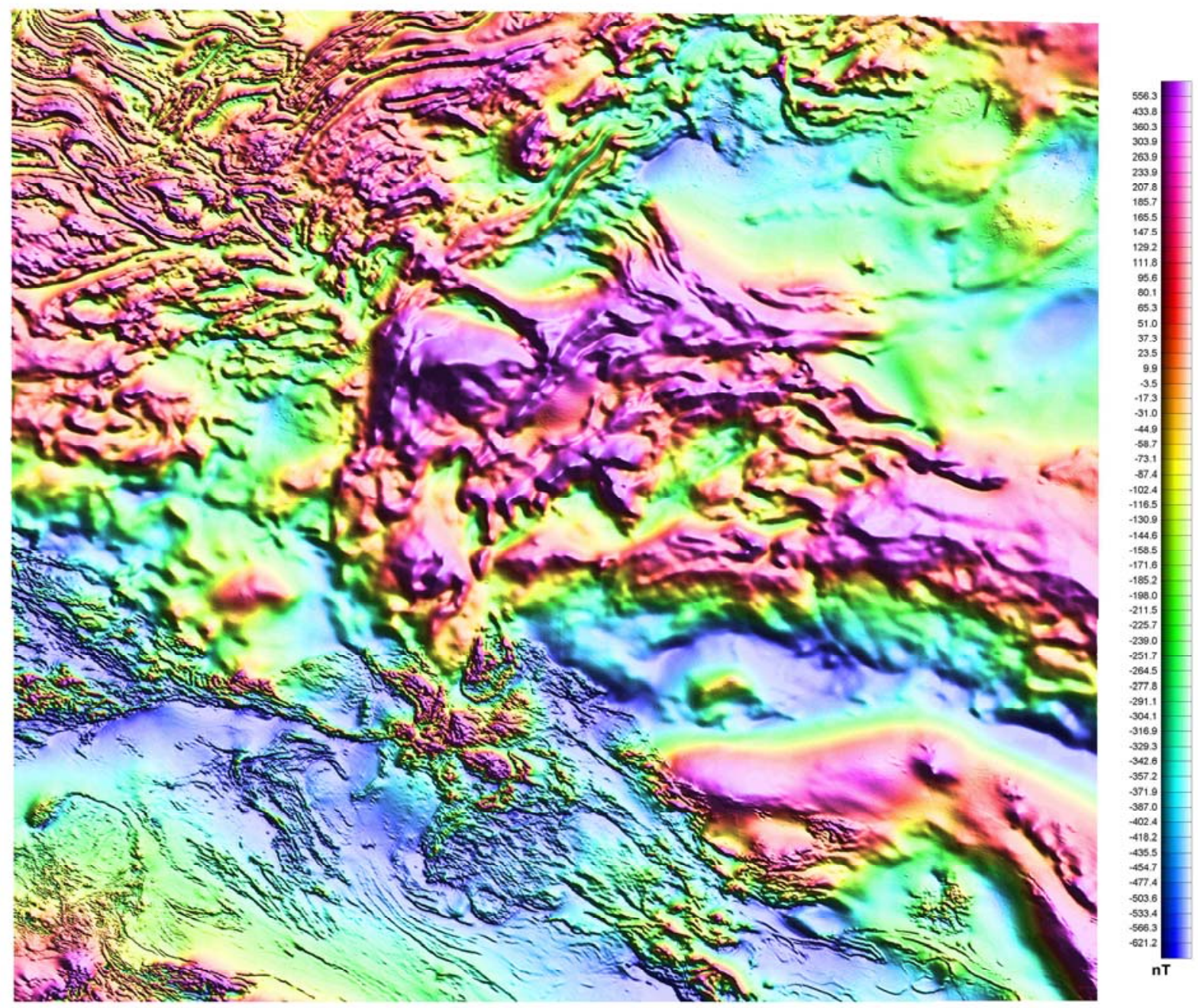

Figure 2: Color shaded TMI image of the Altjawarra Craton and surrounding area.

The central region of the Altjawarra Craton is characterized by an E-W oriented magnetic fabric and is bounded to the north and south by palaeo-rift features of $\sim$ E-W orientation (Figure 3). The southern rift, the Marqua basement domain, underlies a thick accumulation of Cambro-Ordovician carbonatedominated sediments in the Toko Syncline; a similar trough, the Dulcie Syncline, extends to the west. The northern boundary rift is referred to as the magnetic rim to the north of what is interpreted to be a granitoid core. The modelled depth to the magnetic source indicates the platform cover varies from 1 to 2 $\mathrm{km}$ in thickness. Dating of rutile from gneiss intersected toward the base of a stratigraphic well (BMR 12) drilled on the northern margin of the Ooratippra magnetic anomaly, yielded an age of 1685 $\mathrm{Ma}(+/-20 \mathrm{Ma})$, consistent with equivalent zircon dates. There is also evidence for a younger, possibly $1400 \mathrm{Ma}$ granitoid event within the Ooratippra anomaly. 
The Altjawarra Craton is a region of negative Bouguer gravity values reflecting thick crust. There is a strong gravity gradient over the fault system marking the Altjawarra Craton - Davenport Province boundary and local gravity lows within the Altjawarra Craton can be interpreted as rift basins. Gravity data support lineament interpretation seen in the magnetic imagery.
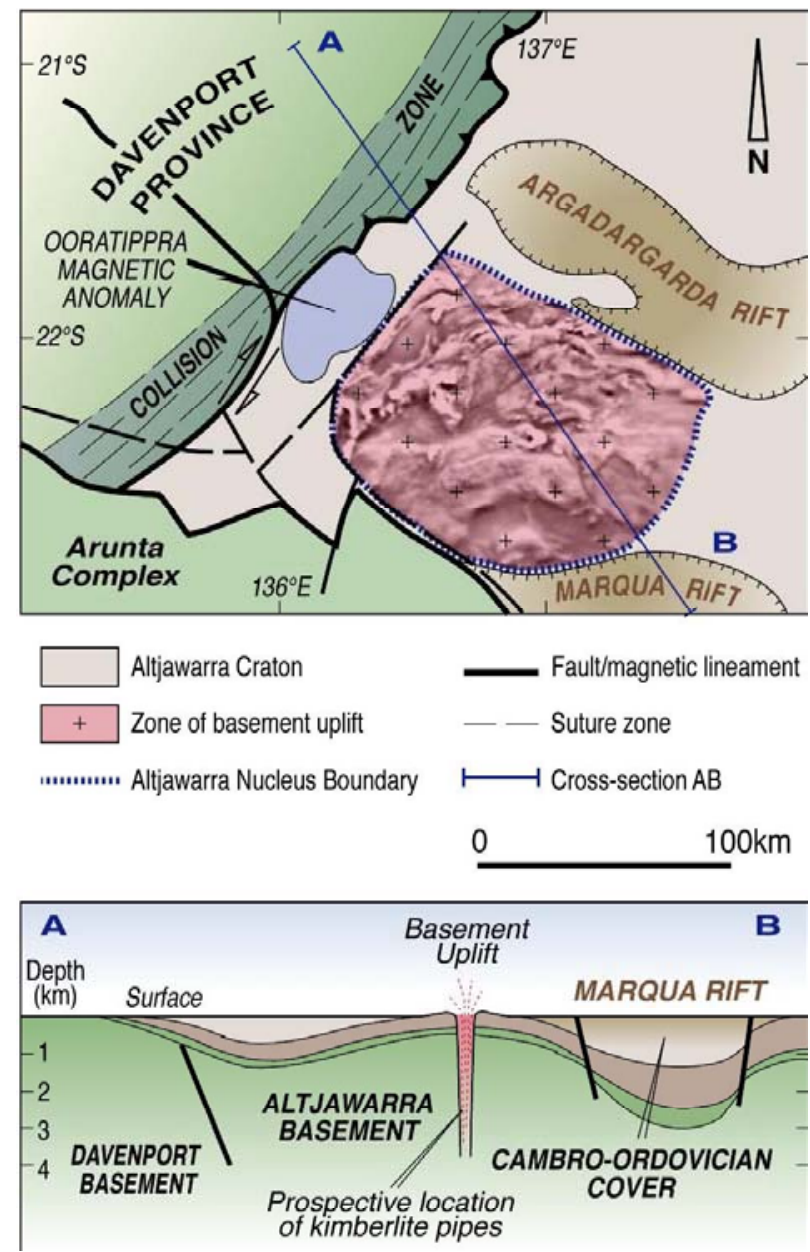

Figure 3: Interpretation of the solid geology of the Altjawarra-Davenport Region.

The Altjawarra Cratonic Nucleus extends for approximately $145 \mathrm{~km}$ in an east-west orientation and $125 \mathrm{~km}$ in a north-south direction, incorporating large expanses of joints, fractures and minor dykes, all of which are characteristic of a granitoid-gneiss terrane. These areas are separated by narrow, high-amplitude linear and curvilinear anomalies, interpreted to represent complexly folded and faulted mafic and ultramafic dominated terranes (or greensone belts) traversed by prominent northeast to north-northeast, west-northwest and east-west structures. The ratio of interpreted granitoids and gneisses to greenstones approximates 80:20, similar to Archaean terranes elsewhere. A $1 \mathrm{~km}$ deep stratigraphic petroleum drillhole (Ross-1) situated over a northeast trending high-amplitude magnetic linear in the central portion of the Altjawarra Craton and north of the Ooratippra anomaly, intersected ilmenite and magnetite-rich basalt, metamorphosed to greenschist facies.

The Altjawarra Cratonic Nucleus has geophysical features that resemble ancient or Archaean-age $(>2,500$ Ma) blocks in other parts of Australia and elsewhere that suggests it may have been preserved as a relatively stable block since early Precambrian times. Recent dating studies of the basement immediately to the east and south of the nucleus, however, have yielded early Proterozoic ages indicating that parts of the Altjawarra craton are composed of younger blocks or have been reworked in Proterozoic times.

Collision of the Altjawarra Craton with the Davenport Province to the northwest is likely to have occurred during consolidation of the North Australian Craton, which was complete by approximately $1,800 \mathrm{Ma}$. A post-collisional northeast trending suture between these blocks is postulated, possibly resulting in intrusion of Mesoproterozoic granitoids, including the Ooratippra basement feature.

\section{COMPARISONS TO SIBERIA}

Geological and geophysical interpretations indicate that the Altjawarra Craton has many features in common with the Yakutian kimberlite province of the East Siberian Platform, where numerous world-class diamond deposits are known (Figure 4).

Interpretation of published data indicates that the Siberian Craton is essentially buried by thick CambroOrdovician sediments. The Craton is bound by a mobile belt to the north and east and by rift and suture zones to the south and west. Diamondiferous kimberlites tend to be located near the central axis of the craton associated with regions of basement uplift where the platform cover is less than about $2 \mathrm{~km}$ thick.

\section{DIAMOND PROSPECTIVITY}

The southern Georgina basin and Altjawarra cratonic nucleus, in particular, are associated with an anomalous zone of very thick lithosphere extending to at least 200 $\mathrm{km}$ depth as recognized from recent seismic tomography studies (Debayle and Kennett, 2000). This lithospheric root is attached to the continental crust of Australia. Because the Australian continent is moving 
north, the presence of the lithospheric root acts like an anchor causing drag in the mantle and stresses in the overlying crust. This is manifest by unusual patterns of seismic anisotropy and crustal stress distribution in the Georgina Basin area. Coinciding with the deep seismic tomographic anomaly is a broad region of anomalously slow crustal velocity

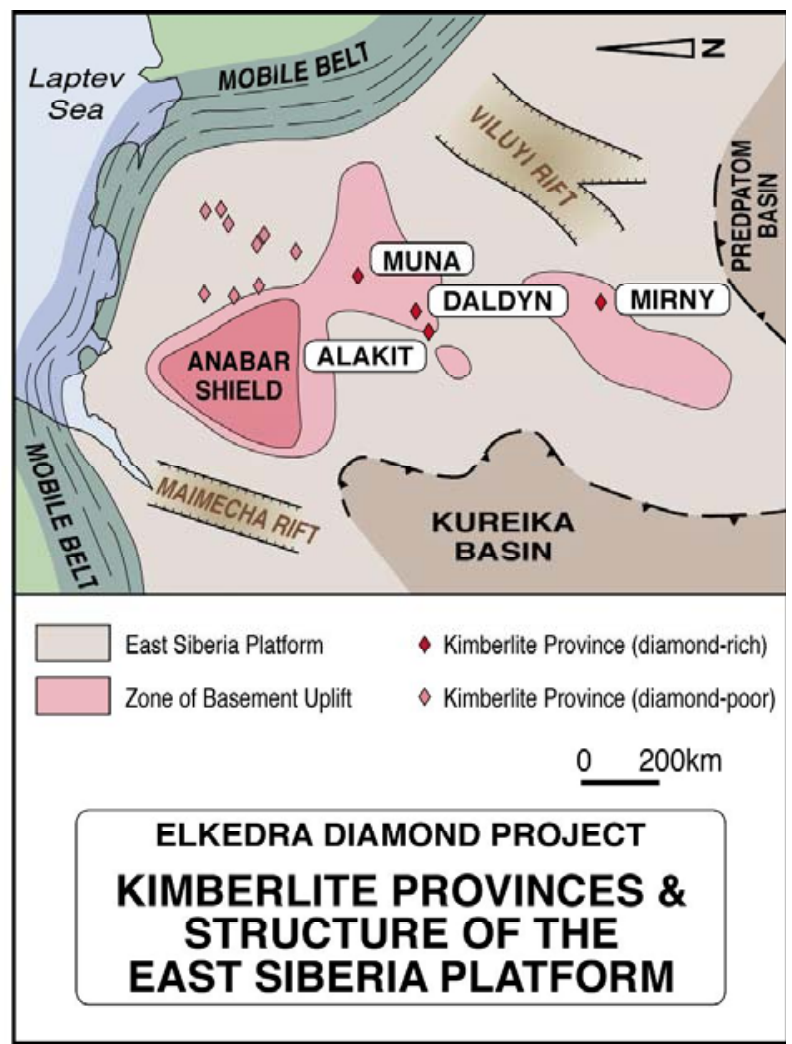

Figure 4: Interpretation of the solid geology of the East Siberia Platform. After Suvorov et al. (1997).

at the base of the crust (42-49 $\mathrm{km}$ depth) indicative of thick crust (Collins and Drummond, 2000). Broadly speaking the region is also characterized by low heat flow and low crustal temperatures at $5 \mathrm{~km}$ depth with small localized and isolated elevated heat sources (Collins and Drummond, 2000). On a regional scale the temperature anomaly is the lowest outside the Archaean Yilgarn and Pilbara blocks of Western Australia, and is consistent with the presence of an ancient, buried cratonic nucleus. All these features are mirrored in ancient cratons, in particular the richly diamondiferous East Siberian Platform, with which the Altjawarra Craton shares many geological and geophysical similarities.

In world-class diamond deposits, the main diamond resource is typically located in the upper levels of a kimberlite pipe. However, many old cratonic regions are uplifted resulting in significant erosion and hence poor preservation of the upper levels of kimberlite pipes. Old cratons with thick platform cover such as the Yakutian kimberlite province of the East Siberian Platform offer the best possibilities for high-level kimberlite pipe preservation. The East Siberian Platform is host to more than ten world class diamond deposits in four major fields (Figure 4).

In the southern Georgina Basin, up to 1.2 kilometres thickness of Cambro-Ordovician sedimentary cover overlies metasedimentary and crystalline basement analogous to the Siberian Platform (Figure 4) where kimberlites have intruded through the sediments to be exposed near-surface or at surface. By analogy this means that potential kimberlites of post-CambroOrdovician age have a high chance of high-level preservation in the Altjawarra region and would also be expected to be present near or at surface. Specifically, the central cratonic nucleaus represents a direct analogy to the East Siberian Platform situation and represents a high-priority regional exploration target. Devonian age kimberlites (approx. 367 million years old) are known from the Merlin field (Lee et al, 1997), providing ample precedent that kimberlite magmatic events of appropriate age exist in the north Australian craton. Coincidentally, the main diamond-bearing kimberlites of Siberia are also Devonian in age between 380 and 350 million years old.

\section{INDICATOR MINERAL RECOVERY}

Parts of the southern Georgina Basin region are well drained and suitable for traditional stream-sediment sampling techniques. Limited open file data show that diamond indicator minerals as well as microdiamonds and macrodiamonds are present in the area. However, most of this earlier work was undertaken peripheral to the Altjawarra cratonic nucleus target, which is characterized at surface by flat, featureless and sand cover terrain precluding traditional stream sediment sampling methods.

Recent work by Elkedra Diamonds NL has led to the recovery of numerous chromite indicator minerals, as well as microdiamonds in and peripheral to the central craton nucleus. Locally, picro-ilmenite as well as $\mathrm{Mg}$ pseudobrookite is also recovered in the peripheral indicator mineral target areas.

Compositions of indicator chromites recovered from regional reconnaissance sampling of the Altjawarra region support an upper mantle origin for many of the 
indicators with some high-Cr chromites sourced from the diamond-stability field (Figure 5).

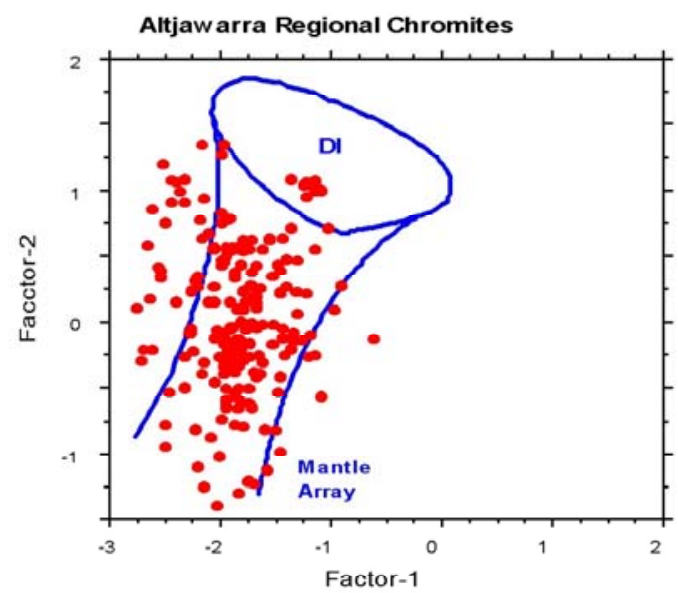

Figure 5: Multi-element discrimination diagram showing compositional fields for chromites from the diamond stability field ("DI") and for chromites from shallower mantle sources ("Mantle Array"). Factors 1 and 2 are multi-element discriminant functions.

\section{SUMMARY}

Compilation of publicly available regional datasets has highlighted the Altjawarra Craton as an area favourable for hosting diamondiferous kimberlites. The Elkedra conceptual model relies on the traditional structural and lithospheric controls for the location of worldclass diamond deposits elsewhere. Early exploration by Elkedra Diamonds is encouraging with indicator mineral results supporting the potential for a primary diamond-bearing host rock in the area.

\section{REFERENCES}

Collins, C., Drummond, B., 2000. Crustal thickness patterns in the Australian continent, Geological Society of Australia Abstracts, 50, 91.

Debayle, E., Kennett, B.L.N., 2000. The Australian continental upper mantle: Structure and deformation inferred from surface waves. Journal of Geophysical Research, 105B11, 25,423 - 25,450.
Clitheroe, G., Gudmundsson, O., Kennett, B.L.N., 1998. Receiver function studies, R.S.E.S. Annual Report 1998, 25-26.

Kennett, B.N., 1997. The mantle beneath Australia. AGSO Journal of Australian Geology \& Geophysics, 17 (1), 49-54.

Lee, D.C., Milledge, H.J., Reddicliffe, T.H., Scott Smith, B.H., Taylor, W.R., Ward, L.M., 1997. The Merlin Kimberlites, Northern Territory, Australia. Russian Geology and Geophysics, 38, 82-96.

Milligan, P.R., Tarlowski, C., 1999. Magnetic anomaly map of Australia, Gradient enhanced residuals of total magnetic intensity, Third edition, Australian Geological Survey Organization, scale 1:5:000,000.

Myers, J.S., Shaw, R.D., Tyler, I.M., 1996. Tectonic evolution of Proterozoic Australia, Tectonics, 15, 1431-1446.

Scott, D., Rawlings, D.J., Page, R.W., Tarlowski, C.Z., Idnurm, M., Jackson, M.J., Southgate, P.N., 2000. Basement framework and geodynamic evolution of the Palaeoproterozoic superbasins of north-central Australia: an integrated review of geochemical geochronological and geophysical data. Australian Journal of Earth Sciences, 47(3), 337-340.

Shaw, R.D., Wellman, P.; Gunn, P.; Whitaker, A.J.; Tarlowski, C., Morse, M., 1996. Guide to using the Australian Crustal Elements Map., Australian Geological Survey Organisation, Record 1996/30, 49p

Sommerville, M.D., Wyborn, D., Chopra, P.N., Rahman, D., Estrella, D., Van der Meulan, T., 1994. Hot-dry rocks feasibility study, Australian Energy Research and Development Corporation, Report 94/243, 133pp.

Suvorov, V.D., Yurin, Y.A., Timirshin, K.V., Krylov, S.V., Parasotka, B.S., Cherny, S.D., Seleznev, V.S., Soloviev, V.M., Matveev, V.D., 1997. Structure and evolution of the crust and uppermost mantle beneath the kimberlite province of Yakutia based on seismic evidence. Russian Geology and Geophysics, 38, 518527.

Van der Hilst, R.D., Kennett, B.L.N., Shibutani, T., 1998. Upper mantle structure beneath Australia from portable array deployment. In: J. Braun et. al., (Eds), Structure and Evolution of the Australian Continent, pp 39-57.

Contact: LA Tompkins, Ground Floor, 23 Ventnor Ave, West Perth, Western Australia, 6005 Australia, E-mail:

linda@elkedra.com.au 